\title{
Characteristics of Vegetation Growing in Indeterminate Fallows in South-Central Zimbabwe
}

\author{
Simbarashe Mudyazhezha ${ }^{1}$, Emmanuel Manzungu ${ }^{1}$, Tawanda Chimombe ${ }^{1}$, Linda Mtali $^{2}$, Bruce Tavirimirwa ${ }^{3} \&$ \\ Sharai Ncube ${ }^{3}$ \\ ${ }^{1}$ Department of Soil Science and Agricultural Engineering, University of Zimbabwe, PO Box MP 167, Mt \\ Pleasant, Harare, Zimbabwe \\ ${ }^{2}$ University of Zimbabwe, Marondera College of Agricultural Science and Technology \\ ${ }^{3}$ Department of Animal Science, University of Zimbabwe, PO Box MP 167, Mt Pleasant, Harare, Zimbabwe \\ Correspondence: Simbarashe Mudyazhezha, Department of Soil Science and Agricultural Engineering, \\ University of Zimbabwe, PO Box MP 167, Mt Pleasant, Harare, Zimbabwe. E-mail: simmudy@hotmail.com
}

Received: February 12, 2013 Accepted: July 10, 2013 Online Published: July 20, 2013

doi:10.5539/enrr.v3n3p78

URL: http://dx.doi.org/10.5539/enrr.v3n3p78

\begin{abstract}
Despite widespread food insecurity in Zimbabwe, there is an increasing amount of agricultural land being left fallow for indeterminate periods of time. The objective of the study was to assess the characteristics of vegetation growing in indeterminate fallows in Chivi district in south-central Zimbabwe. One metre by one metre quadrats were used to assess the species composition of herbaceous species while $8 \mathrm{~m} \times 8 \mathrm{~m}$ quadrats were used for woody species. Attributes that were assessed included frequency, abundance, density of different plant species from which were computed diversity indices (Shannon-Weiner index and Shannon evenness index). The density, Shannon-Weiner index and Shannon Evenness index, and species richness of the fallow land sites were significantly lower than those of the uncultivated land. However, there were no significant differences among fallow treatments. Species richness, Shannon Index, and Shannon's Evenness Index showed a weak and non significant correlation with length of the fallow period. Woody species, which were cleared during land preparation and repeatedly weeded during the cultivation years were absent in all fallows regardless of the fallow period.
\end{abstract}

Keywords: agricultural land, indeterminate fallows, vegetation, species composition, species diversity

\section{Introduction}

In Zimbabwe, rural areas that are under communal land tenure locally known as communal areas, occupy 16.4 million ha that is equivalent to $42 \%$ of the national land and accommodate $70 \%$ of the national population (Muir-Leresche, 2004). The livelihoods of the majority of the approximately 6-7 million people that are resident in these areas are agriculture-dependent (Moyo, 2006). However, agriculture is severely constrained by, among other factors, soils that are of inherent poor physical and chemical fertility and low organic matter content (Nyamadzawo et al., 2003). Consequently crop production is severely limited by nutrient deficiencies (Zingore et al., 2007) since most farmers cannot afford to buy the needed inorganic fertilizers (Manzungu \& Mtali, 2012). The situation is made worse by low and erratic rainfall with $75 \%$ of the area receiving less than $600 \mathrm{~mm}$ of rainfall per year (Muir-Leresche, 2006). This is why, on the basis of agro-ecological conditions that are based on rainfall patterns, most of the country's communal lands are designated as only suitable for livestock production (Whitlow, 1985). However, because of the country's colonial history, which has left the majority of the 1 million smallholder farming households without many options, farming continues to be undertaken, albeit with a high failure rate (Muir-Leresche, 2006). For every five agricultural seasons, farmers in communal areas only get good harvest in two seasons.

The poor prospects for successful crop production have resulted in a situation where an increasing proportion of agricultural land in Zimbabwe is being left fallow (Mapfumo et al., 2005). This is a paradox given the widespread food insecurity (Manzungu \& Mtali, 2012). To date, interventions in Zimbabwe to address the problem of increasing fallow have focused on ways and means of increasing crop production (Mapfumo et al., 2005). Despite the availability of such measures the proportion of fallow land does not seem to be decreasing. A recent study 
showed that as much as $50 \%$ of the land that was cultivated since the 1980s is fallow for indeterminate periods of time (Manzungu \& Mtali, 2012). This phenomenon of agricultural land being left fallow for indeterminate periods of time with no prospect of being re-cultivated has been reported to be on the increase (Nyoka et al., 2004). Such indeterminate fallows are being used for grazing areas to supplement the generally inadequate grazing areas in terms of quantity and quality which is worsened by disproportionate large livestock numbers (Sibanda \& Khombe, 2006). In other countries, fallows have been reported to be sources of fuelwood and timber (Wadsworth, 1997), edible and medicinal fruits (Voeks, 1996) and providers of environmental services such as protection from erosion and atmospheric carbon fixation (Fearnside \& Guimaraes, 1996).

Despite the increasing use of indeterminate fallows for grazing in Zimbabwe, there are no known studies that have investigated the characteristics of secondary vegetation as well as its grazing quality. Such a study is critical since most of the information on the subject of vegetation recovery originates from wet subtropical areas (Colon $\&$ Lugo, 2006). This paper reports on a study whose objective was to assess the characteristics of the secondary vegetation growing in indeterminate periods of fallow land as well as the forage quality of the grasses found therein. The study was based in an area in south central Zimbabwe that typifies many communal lands of Zimbabwe. The area is characterised by low and erratic rainfall and poor soils, and increasing fallow land that is used for grazing (Manzungu \& Mtali, 2012).

\section{Materials and Methods}

\subsection{Site Description}

The study was carried out in Chivi district that is located in south central Zimbabwe some $400 \mathrm{~km}$ away from the capital city of Harare. It extends from $20^{\circ} 14^{\prime} \mathrm{S}$ to $20^{\circ} 24^{\prime} \mathrm{S}$ and lies between $30^{\circ} 13^{\prime} \mathrm{E}$ and $30^{\circ} 57^{\prime} \mathrm{E}$ (Mapanda \& Mavengahama, 2011). Chivi district falls in agro-ecological region 5 that receives an annual rainfall of $400-500 \mathrm{~mm}$ and is one of the driest in the country (Nyamadzawo et al., 2003). Land pressure in the district is high, with an average size of arable land holding of about 2 ha per household (Mavedzenge et al., 1999).

As a consequence of low and erratic rainfall and poor soil fertility, crop production of even drought tolerant crops, is a challenge. Due to the poor crop yields that are attained, people in the district rely on food aid from the government and non-governmental agencies (Mapanda \& Mavengahama, 2011). The research was carried out in ward 28, which in many ways is representative of the district. Field work was conducted in four out of the 19 villages. The total number of households in the four villages amounted to 130 .

\subsection{Vegetation Characteristics}

The study was undertaken in plots of different fallow periods, which constituted the treatments (Table 1). A completely randomized experimental design with three replications was used. A nearby stretch of land that was classified as non-arable (Manzungu \& Mtali, 2012) and had not been cleared for agriculture was used as the control.

Table 1. Plots used to study vegetation characteristics in ward 28, Chivi district in south central Zimbabwe

\begin{tabular}{ll}
\hline Plot & Length of fallow period (years) \\
\hline 1 & $0-2$ \\
2 & $3-5$ \\
3 & $6-10$ \\
4 & $11-15$ \\
5 & $16-35$ \\
6 & Control \\
\hline
\end{tabular}

Source: Manzungu and Mtali (2012).

Samples of vegetation, that included grasses, herbaceous species, shrubs and woody tree species, were collected in February 2011. A $1 \mathrm{~m} \mathrm{x} \mathrm{1m} \mathrm{quadrat} \mathrm{was} \mathrm{randomly} \mathrm{thrown} \mathrm{three} \mathrm{times} \mathrm{in} \mathrm{each} \mathrm{plot} \mathrm{in} \mathrm{order} \mathrm{to} \mathrm{assess} \mathrm{grass} \mathrm{and}$ herbaceous species. In each plot the number of grasses and herbs species were counted and recorded. An $8 \mathrm{~m} \times 8$ $\mathrm{m}$ subplot randomly placed was used for the enumeration of shrubs and trees. Across all vegetation types, effort was made to identify the species in the field. Samples of those species that could not be identified in the field were preserved and taken to the National Herbarium in Harare for identification. Grass and herbaceous species 
were uprooted using a knife and entire plants preserved in plant pressers to maintain their colour, roots and flowers. For trees and shrubs, small branches with leaves and fruits, and the bark were cut from trees and preserved in brown envelopes for identification at the National Herbarium.

Species richness (S) was determined by counting the number of species in a plot while diversity was determined by calculating Shannon-Weiner index. The Shannon-Wiener index $\left(\mathrm{H}^{\prime}\right)$ was calculated using the formula:

$$
H^{\prime}=-\sum_{i=1}^{s} \text { pi ln pi }
$$

where $\mathrm{s}=$ number of species, and $\mathrm{pi}=$ proportion of individuals per species in the community made up of $\mathrm{s}$ species with known proportions p1, p2, p3, ..., ps. To quantify the evenness component of diversity, evenness index or Shannon-evenness index $1\left(\mathrm{E} 1=\mathrm{H}^{\prime} / \ln \mathrm{S}\right)$ was computed.

Density was calculated as number of individuals divided by area sampled while relative density was determined as (density for a species)/(total density for all species)*100. Normality tests were performed on species richness, Shannon Weiner index, evenness index, frequency and density. After meeting the normality tests, one way Analysis of Variance (ANOVA) was used to test for statistical differences in the above parameters across the various treatments. Hierarchical Cluster Analysis (HCA) using the average linkage method was performed to determine the similarities amongst the treatments with regards to species composition.

\section{Results}

\subsection{Vegetation Characteristics}

\subsubsection{Species Richness, Diversity and Dominance}

A total of 68 plant species were collected and identified from the fallow fields and the woodland of which 15 species were grasses, 33 herbs, 11 shrubs and 8 trees (Table 2). Fallow fields were dominated mainly by grasses and herbs, with sparse tree species around the edges of fields near water-ways while the non-arable control was dominated by trees.

Table 2. The mean densities of grasses, herbs and trees in different plots in Chivi district, south central Zimbabwe.

\begin{tabular}{llll}
\hline Fallow period (years) & Grasses $\left(\right.$ per $\left.\mathrm{m}^{2}\right)$ & Herbs $\left(\right.$ per $\left.\mathrm{m}^{2}\right)$ & Trees (per ha) \\
\hline $0-2$ & $248 \pm 47.31$ & $97 \pm 23.87$ & 0 \\
$3-5$ & $235 \pm 69.05$ & $51 \pm 17.43$ & 0 \\
$6-10$ & $483 \pm 73.71$ & $32 \pm 9.14$ & 0 \\
$11-15$ & $145 \pm 55.82$ & $99 \pm 29.65$ & 0 \\
$16-35$ & $189 \pm 44.56$ & $23 \pm 7.61$ & 0 \\
Control & $62 \pm 14.74$ & $47 \pm 11.02$ & $307 \pm 61.89$ \\
\hline
\end{tabular}

The total number of grass species showed an increase with fallow period up to 6-10 years where a peak value of 483 grasses per $\mathrm{m}^{2}$ was observed. This value was slightly more than double compared to that of $0-2$-year fallow period and almost eight times that of the control. There were significant differences in the number of herb species among the six treatments $(\mathrm{P}<0.05)$. There were more herb species in the control than in the fallows. All fallow stands did not have any shrub or tree. A total of 11 shrubs and 9 tree species were found in the control. 
Table 3. Mean densities of individual grass species $\left(\mathrm{m}^{-2}\right)$ across the six plots ( 5 fallow periods and control) in Chivi district in south central Zimbabwe.

\begin{tabular}{lcccccc}
\hline \multicolumn{7}{c}{ Fallow period (Years) } \\
\hline Species & $0-2$ & $3-5$ & $6-10$ & $11-15$ & $16-35$ & Control \\
Perotis paterns & $57 \pm 19.67$ & $29 \pm 20.98$ & $49 \pm 23.93$ & $64 \pm 38.71$ & $51 \pm 30.37$ & 0 \\
Cynodon dactylon & $163 \pm 117.08$ & $187 \pm 91.12$ & $7 \pm 7.65$ & $13 \pm 7.55$ & $31 \pm 16.68$ & $9 \pm 3.35$ \\
Digitaria eriantha & $20 \pm 8.67$ & $8 \pm 5.16$ & $14 \pm 8.09$ & $40 \pm 23.93$ & $20 \pm 13.63$ & 0 \\
Digitaria longiflora & $5 \pm 5.73$ & $5 \pm 5.73$ & $7 \pm 6.84$ & $1 \pm 1.23$ & $1 \pm 1.73$ & $13 \pm 6.58$ \\
Brachiaria & $1 \pm 1.34$ & 0 & $54 \pm 42.55$ & 0 & $61 \pm 24.17$ & 0 \\
Pogonarthria squarossa & 0 & $4 \pm 3.94$ & $6 \pm 4.01$ & $6 \pm 4.21$ & $1 \pm 1.73$ & 0 \\
Hyperthelia dissoluta & 0 & 0 & $12 \pm 7.98$ & $20 \pm 21.80$ & $20 \pm 24.99$ & 0 \\
Panicum maximum & 0 & 0 & 0 & 0 & 0 & $20 \pm 5.32$ \\
Mariscus macer & 0 & 0 & 0 & 0 & 0 & $16 \pm 11.05$ \\
Urochloa mosambiausis & 0 & 0 & 0 & 0 & 0 & $2 \pm 2.5$ \\
\hline
\end{tabular}

Table 3 shows that Panicum maximum, Mariscus macer and Urochloa mosambiausis were absent in all fallow lands. Panicum maximum was found to be the most dominant species in the control while Cynodon dactylon was the most dominant grass species in the 0-2 year and 3-5 year fallows with densities of 163 and 187 individual stems per $\mathrm{m}^{2}$ respectively. C. dactylon was also present in the control with a density of 3 stems per $\mathrm{m}^{2}$. Pogonarthria squarossa only appeared after 2 years of fallow while Hyperthelia dissoluta was only present from 6 years of cessation of cultivation. Both were absent in the control. Perotis paterns, was the second most dominant grass species in the 0-2 yr and 3-5 year fallow, the most abundant in the 6 year fallow onwards and absent in the control (Table 3). The densities of grasses found in the fallow did not show any pattern with fallow period. Richardia scabra was the most abundant non grass herb in the 0-2 yr and 3-5 year fallows. It was also present in the control with 3 individuals per $\mathrm{m}^{2}$. Zonia gluchidiata dominated the 6-10 yr and 11-15 year fallows. Phyllanthus fracternus, Acanthacea fimbriata, Acanthacea spp and Malvacea species were only present in the control. Rubiacea species and Bergia decumbens were found in fallow periods of 6 years upwards but were absent in the control. Triumfetta rhomboidea was present in fallows younger than 6 years. It was the non-grass herb with the highest density in the control with 16 individuals per $\mathrm{m}^{2}$. Zonia gluchidiata was the most abundant species in the fallows and the least abundant in the control with 2 stems per $\mathrm{m}^{2}$. Indigofera astragalina was the second most densely populated in the fallows while Chamecrista absis was the fourth most abundant species in the fallows. Both I. astragalina and C. absis were absent in the control (Table 4).

Table 4. Mean densities of non grass herbaceous species $\left(\mathrm{m}^{-2}\right)$ found across the six plots in Chivi district in south-central Zimbabwe.

\begin{tabular}{lllllll}
\hline \multicolumn{7}{c}{ Fallow period (Years) } \\
\hline Species & $0-2$ & $3-5$ & $6-10$ & $11-15$ & $16-35$ & Control \\
Richardia scabra & $23 \pm 14.96$ & $31 \pm 17.44$ & $2 \pm 1.57$ & $6 \pm 4.65$ & $7 \pm 5.41$ & $3 \pm 3.36$ \\
Chamecrista absus & $19 \pm 16.59$ & 0 & $0 \pm 0.74$ & $1 \pm 0.84$ & $3 \pm 2.65$ & 0 \\
Indigofera astragalina & $28 \pm 22.19$ & $4 \pm 2.49$ & $2 \pm 2.57$ & $13 \pm 14.96$ & $9 \pm 9.09$ & 0 \\
Ocimum americanum & $2 \pm 2.58$ & $3 \pm 3.76$ & $1 \pm 1.34$ & 0 & 0 & 0 \\
Zonia gluchidiata & $22 \pm 17.53$ & $2 \pm 1.68$ & $16 \pm 11.51$ & $68 \pm 43.67$ & $1 \pm 1.73$ & $2 \pm 2.88$ \\
Triumfetta rhomboidea & $1 \pm 1.34$ & $1 \pm 1.34$ & 0 & 0 & 0 & $16 \pm 9.24$ \\
Rubiacea spp & 0 & 0 & $1 \pm 1.34$ & $5 \pm 2.68$ & $1 \pm 1.5$ & 0 \\
Bergia decumbens & 0 & 0 & $2 \pm 1.3$ & $3 \pm 2.83$ & $1 \pm 1.5$ & 0 \\
Phyllanthus fracternus & 0 & 0 & 0 & 0 & 0 & $2 \pm 1.89$ \\
Acanthacea fimbriata & 0 & 0 & 0 & 0 & 0 & $4 \pm 3.73$ \\
Acanthacea spp & 0 & 0 & 0 & 0 & 0 & $4 \pm 4.04$ \\
Malvacea species & 0 & 0 & 0 & 0 & 0 & $4 \pm 3.51$ \\
\hline
\end{tabular}


Table 5 shows the species richness, diversity and dominance of different species across the treatments. The control was found to have significantly higher species richness $(S)$ than the fallows lands $(P<0.05)$. This was because in addition to having grasses and herbs, it was the only piece of land which had woody species. The control was also found to have significantly higher $(\mathrm{P}<0.05)$ density-based Shannon-Wiener diversity index values $\left(\mathrm{H}^{\prime}\right)$ and density-based evenness index values (Table 5). The different fallow periods did not show significant variation in dominance $(\mathrm{F}=2.27, \mathrm{P}=0.085)$. There were, however, no significant differences in grass species numbers among the six treatments $(\mathrm{P}<0.05)$. Shannon-Weiner index and Shannon evenness index also did not show any significant variation among the fallow lands of different ages.

Table 5. Means of species richness (S), Shannon-Weiner index $\left(H^{\prime}\right)$; Shannon Evenness Index $\left(\mathrm{e}^{\wedge} \mathrm{H} / \mathrm{S}\right)$ in different plots in ward 28 of Chivi district, south-eastern Zimbabwe

\begin{tabular}{llll}
\hline Period (yrs) & $\mathrm{S}$ & $\mathrm{H}^{\prime}$ & $\mathrm{e}^{\wedge} \mathrm{H} / \mathrm{S}$ \\
\hline $0-2$ & 15 & 1.24 & 0.6 \\
$3-5$ & 19 & 0.99 & 0.4 \\
$6-10$ & 20 & 1.42 & 0.71 \\
$11-15$ & 15 & 1.18 & 0.57 \\
$15-35$ & 16 & 1.49 & 0.6 \\
Undisturbed & 41 & 2.42 & 0.56 \\
\hline
\end{tabular}

Hierarchical Cluster analysis could only separate the treatments into two clusters. Cluster one had all the sites from the fallow treatments while cluster two exclusively contained the sites from the control. The control treatments separated from the fallow treatments because of the presence of the woody species which were nonexistent in the fallows. There were no differences among the treatments in relation to species composition among the fallows of different ages.

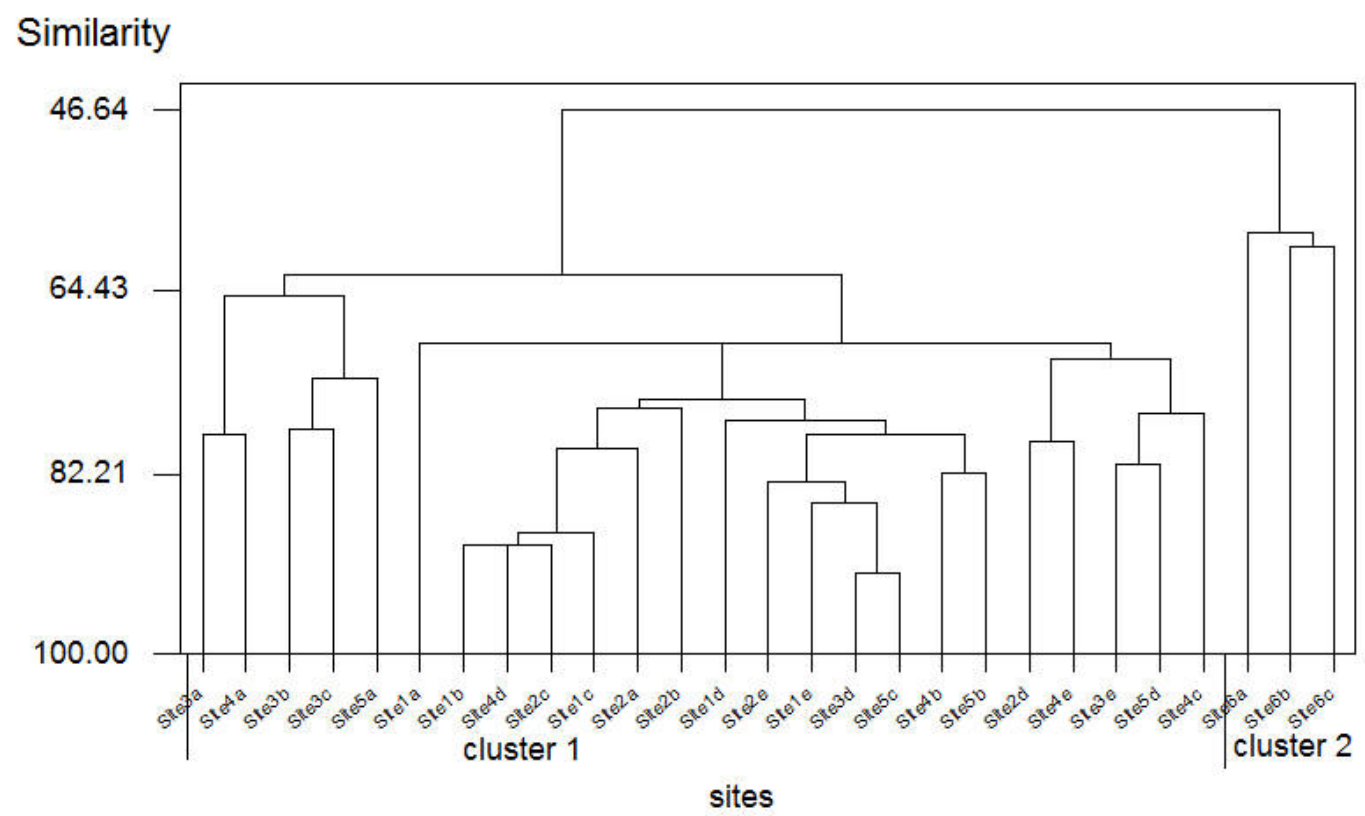

Figure 1. Dendogram of Hierarchical Cluster Analysis (HCA) based on presence/absence data for vegetation growing in different fallows in Chivi District, south cental Zimbabwe

Regression analyses of the diversity indices (Species Richness, Shannon Index, Simpson Index, and Shannon's Evenness Index) along the developmental stages indicated weak correlations which were not significant. Species richness was found to have a weak negative correlation with age of the fallow $\left(\mathrm{R}^{2}=0.056, \mathrm{P}=0.70\right)$. Shannon 
Index and the Shannon Evenness Index showed weak and non significant positive correlation with length of the fallow period (Shannon Index: $\mathrm{R}^{2}=0.39, \mathrm{P}=0.259$; Evenness Index: $\mathrm{R}^{2}=0.047, \mathrm{P}=0.726$ ). Simpson Index had a more positive correlation. However, the relationship with lengthy of the fallow period was not significant $\left(\mathrm{R}^{2}=\right.$ $0.69, \mathrm{P}=0.082$ ) (Figure 2).

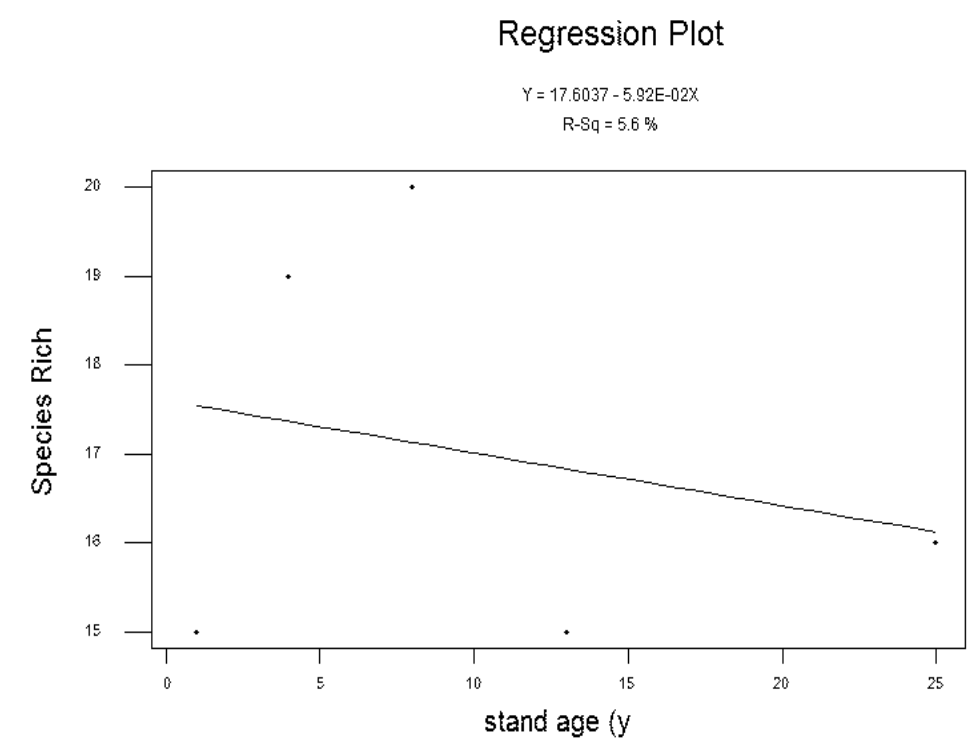

Figure 2. Correlation between fallow period and species richness for vegetation growing in different fallows in Chivi District, south cental Zimbabwe

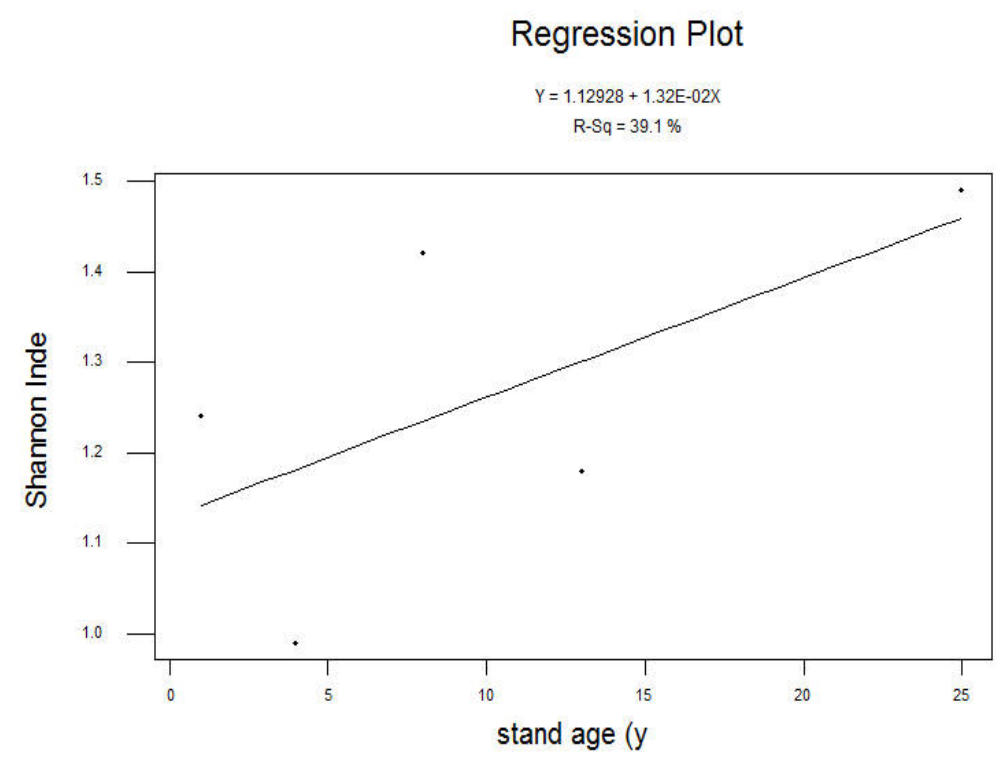

Figure 3. Correlation between fallow period and Shannon index for vegetation growing in different fallows in Chivi District, south cental Zimbabwe 


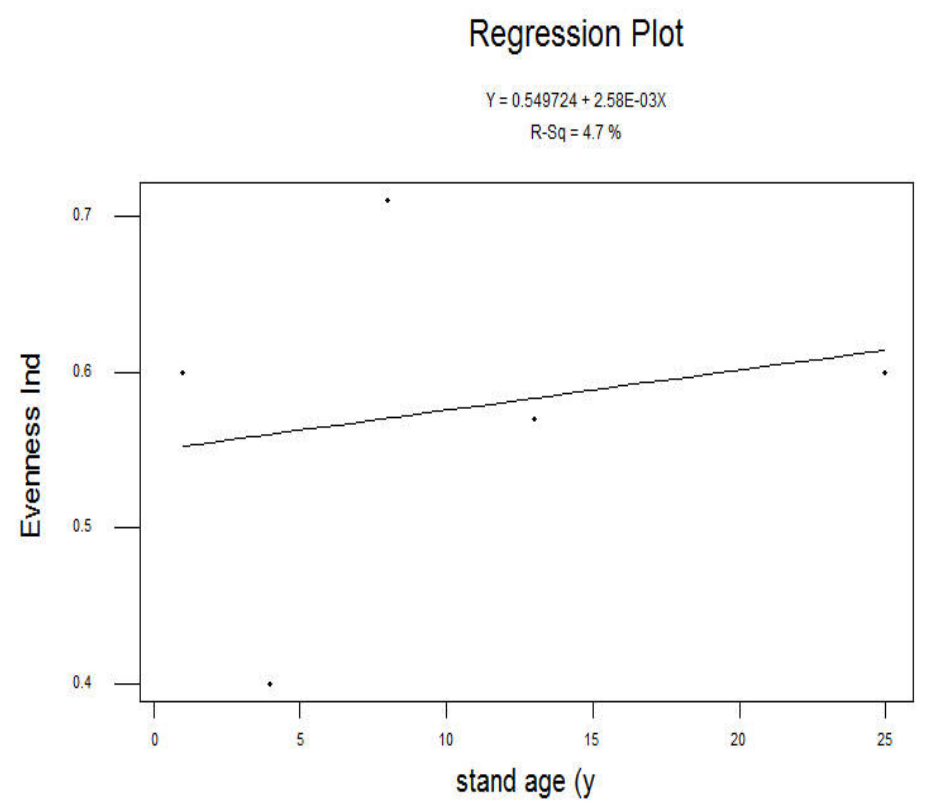

Figure 4. Correlation between fallow period and Shannon's Evenness index for vegetation growing in different fallows in Chivi District, south cental Zimbabwe

\section{Discussion}

\subsection{Vegetation Characteristics}

The structure and composition of fallow vegetation is influenced by factors such as: the method of clearing; length; intensity of the preceding cultivation period (which among other things determine the number and vigour of active stubs); frequency of fire; availability of seed sources and dispersers; the length of the fallow period; the soil (texture, structure, drainage and fertility) as well as the grazing, browsing and trampling intensity (Ohler, 1985). These interacting factors lead to different vegetation types, dominated (apart from stand-overs) by annual and/or perennial grasses and/or thorny or thornless shrubs or trees (Guariguata \& Ostertag, 2001). However, these factors are site-specific (Guariguata \& Ostertag, 2001), hence the need for detailed local assessment as was carried out in this study. This explains why patterns of vegetation observed in this study were quite different from other fallow recovery studies. Most natural fallows in high rainfall areas manage to develop secondary vegetation which includes shrubs and trees as years of fallow progress (Ngobo, 2004; Hooper et al., 2005). This was however, hindered in fallows found in Chivi district because of the low and erratic rainfall, poor soil fertility and overgrazing by livestock.

The fact that more species were found in the control than in the fallows and there were neither trees nor shrubs in the fallow fields can be attributed to complete removal of coppicing trees in preparation for cultivation. After cutting, burning and weeding have largely eliminated mechanisms of on-site regeneration, the only way for woody species to re-establish is by seed dispersal. This dependence on seed dispersal seriously slows succession because forest species are not readily dispersed to fallow lands. According to Uhl (1987) 54\% of the 192 Ocotea costulata diaspores placed in the farm study site were removed (presumably by animals) within four days, and all had disappeared after one month. Jessenia bataua also showed a similar trend, with all but one of 192 diaspores being removed within one month of placement in the farm site. Uhl (1987) concluded that many more woody individuals could have been packed onto the main study site if propagules were available.

In addition to poor seed dispersal, competition with herbaceous vegetation (Holle et al., 2000), soil compaction and low soil nutrients (Reiners et al., 1994), or photoinhibition can inhibit the initial establishment of woody species in many tropical sites (Aide et al., 2000). Forbs and grasses are able to germinate, flower and set seed in the interval between weedings and, therefore, can build up high densities and large seed banks in fallows. In contrast, the woody pioneer species, which establish from the seeds surviving the burn, are weeded from the site before they have had time to produce seeds (Uhl, 1987). This could possibly explain the absence of wood species since they were weeded out annually during the cultivation period before they could produce seeds.

Soil water availability is generally considered critical factor for determining the development of woody 
vegetation (Frensham \& Holman, 1999). Classical models suggest that water is the key resource in determining tree densities although other important variables like fire and grazing can maintain the population below their climatic equilibrium (van Wijk \& Rodriguez-Iturbe, 2002). According to the savannah literature, grasses utilize the topsoil water while tree roots have exclusive access to deeper water, creating a clear niche separation (Weltzin \& Coughenour, 1990). This allows grasses and trees to co-exist without one competitively excluding the other for soil moisture. The high numbers of grasses observed in the control supports this water resource partitioning theory.

The presence of more herbs in the woodland could have been a result of the presence of deep rooted trees and shrubs. These have the capacity to pump leached nutrients making them available (through decomposition of their leaf litter and other organic components) to other plants growing on the surface.. Nitrogen fixing species increase the amount of nitrogen available for the herb species (Nepstad et al., 1996). The varied growth forms of herb species, which are upright, trailing or creeping also allows them to colonize woodlands with more competitive shrubs and trees as they can compete well for light and nutrients (McClanahan \& Wolfe, 1993).

The higher species richness in the control compared to fallow lands can be explained by the suitable conditions for regeneration in the former. The remaining tree species created favourable conditions. Under canopies germination and establishment of different (tree) species is higher since seedlings are protected from high temperatures and moisture stress as well as being provided with nutrients through falling and decomposing leaves (Holl et al., 2000). The presence of higher organic matter content in the control due to decaying litter could also have facilitated the establishment of herbs and trees. Organic matter plays an important role in nutrient and moisture retention and favours the establishment of wide leaved herbaceous plants which are more sensitive to low moisture levels compared to grasses (Holl et al., 2000). The lack of significant differences in species richness and diversity (Shannon-Weiner Index) among the fallows showed that species richness was not necessarily a function of time only but may be affected by other environmental conditions such as soil fertility and continuous disturbance such as grazing.

The dominance of grasses in fallow fields such as Cynodon dactylon and Perotis paten showed that they were adapted to sandy soils with low nutrient levels. Cynodon dactylon is a grass which is adapted over a broad range of soil pH (4.5-8.5) (http:/www.tropicalforages.info/key/Forages/Media/Html/Cynodon-dactylon.htm, May 2011). This explains its presence in acidic soils of Chivi district. $C$. dactylon is a rhizomatous perennial grass that propagates mainly vegetatively, through stolon and rhizome fragmentation (Fenandez, 2003). It is also a drought and salt tolerant species. A major component of the drought resistance is the development and maintenance of a deep, extensive and viable root system and proline content (Marcum et al., 1995; Carrow, 1996, Huang et al., 1997b). This enables it to grow it Chivi, which is a drought prone area with annual rainfall erratic and usually below $650 \mathrm{~mm}$. In addition to the above characteristics, C. dactylon is extremely tolerant of heavy grazing, thus explaining its abundance in the overgrazed areas of Chivi.

C. dactylon is a low-growing $\mathrm{C} 4$ weed that is highly sensitive to shading (Whittaker, 2001). Plants with a $\mathrm{C}_{4}$ metabolism have been shown to have physiological advantages in productivity over $\mathrm{C}_{3}$ species under conditions of higher light intensities, high leaf temperatures and reduced stomatal conductances (Chapin et al., 1987). However, C. dactylon lacks some specific attributes to compete against tall crops since it is a low growing herb. This species therefore shows severe biomass reductions and highly plastic morphological changes in response to resource availability. Severe biomass reduction of $C$. dactylon was observed as a result of light competition by maize even when nitrogen and water were not limited (Guglielmini \& Satorre, 2002). This shade intolerance could possibly explain its absence in the control area where canopy cover from the trees causes severe shading. Tillage has been mentioned as important factor enhancing colonization of $C$. dactylon in the pampas cropping systems (Guglielmini \& Satorre, 2002). This could be the reason why the fallow lands are infested by $C$. dactylon since they were once under tillage.

Perotis paten was also dominant in the fallows due to its ability to produce a large proportion of viable seeds which are well adapted to dry land conditions. It has also thick stems just above the roots which concentrate nutrients and protect the meristems when conditions are too dry, which allows the grass to re-sprout quickly when favorable conditions are restored (Whittaker, 2001). It is a perennial weed native to South America and prevalent in disturbed soils of southern coastal plains of the U.S., Mexico, South Africa, Indonesia and Hawaii. (Chandran \& Singh, 2003). This explains its prevalence in the fallows and absence in the control where disturbance was minimum.

Grasses like Panicum maximum and Urochloa mosambioausis, which were not found in the fallows and least abundant in the control because they are less adapted to low rainfall conditions and poor fertile soils. These 
grasses were present in the control area where the conditions were more moist and fertile than those in the fallows. Such conditions are required to reach the reproductive stage (Whittaker, 2001). Pacimum maximum (guinea grass) grows on a variety of well drained soils of good fertility and in areas receiving more than $900 \mathrm{~mm}$ rainfall (Aganga \& Tshwenyane, 2004). Aphelandra aurantiaca is an understorey herb (Calvo-Irabien and Islas-Luna, 1999). This explains why it was absent in the fallows where there are no trees and yet present in the control where there are trees to provide cover. Malvaceae is a polymorphic perennial herb of open moist, sunny to partly shaded riverine habitats (Spooner et al., 1985), hence its presence in the control which is an open and moist woodland.

Higher grass densities were found in the fallows than in the control. Although the effect is not consistent, the most common effect of trees in the tropical grasslands is to reduce the herbaceous yield beneath the canopy (Mordelet \& Manaut, 1995). While there is substantial evidence that trees augment nutrient levels in the soil beneath their canopies, increases in herbaceous yield do not necessarily result when there is nutrient enrichment. If available light is insufficient for photosynthesis, no positive response can be expected (Mordelet \& Manaut, 1995). Therefore, while in the control, there is likely to be high nutrient levels, inadequate light reduces the grass biomass. The interaction between trees and grasses is affected by a variety of factors. These factors include rainfall (Belskey et al., 1993a) and grazing (Belsky et al., 1993b). Differences in species composition under and away from savanna trees are more distinct in low than in high rainfall zones suggesting that environmental gradients are stronger in habitats where effects of radiant energy regime or root competition have a greater influence in species interactions (Whittaker, 2001). This may explain why some species are found in the fallows which are open grassland and not in the control which is a wooded savanna. Grazing and browsing pressure may also alter patterning of herbaceous vegetation in savannas. In heavily grazed savannas, few differences between tree-crown and grassland zones may occur (Whittaker, 2001).

\section{Conclusions}

Results of the this study indicated that in the dry region of Chivi district, a fallow period of up to 30 years had no effect on vegetation characteristics (richness and diversity). This suggests that regeneration of vegetation is not only a function of time but may be due to other environmental conditions such as poor rainfall and low fertility as well as continuous grazing, which resulted in trees and shrubs failed to establish in Chivi fallow fields over a period of 30 years.

\section{References}

Aganga, A. A., \& Tshwenyane, S. O. (2004). Potentials of guinea grass (Panicum maximum) as forage crop in livestock production. Pakistan Journal of Nutrition, 3(1), 1-4. http://dx.doi.org/10.3923/pjn.2004.1.4

Aide, T. M., \& Cavelier, J. (1994). Barriers to tropical lowland forest restoration in the Sierra Nevada de Santa Marta, Colombia. Restoration Ecology, 2, 219-229. http://dx.doi.org/10.1111/j.1526-100X.1994.tb00054.x

Aide, T. M, Zimmerman, J. K., Pascarella, J. B., Rivera, L., \& Marcano-Vega, H. (2000). Forest regeneration in chronosequecnce of Tropical Abandoned pasture: Implications for Restoration Ecology. Restoration Ecol., 8, 328-338. http://dx.doi.org/10.1046/j.1526-100x.2000.80048.x

Amundson, R. G., Ali A. R., \& Belsky, A. J. (1995). Stomatal responsiveness to changing light intensity increases rain-use efficiency of below-crown vegetation in tropical savannas. J. Arid. Environ., 29, 139-53. http://dx.doi.org/10.1016/S0140-1963(05)80085-0

Belsky, A. J., Mwonga, S. M., Amundson, R. G., Dux-bury, J. M., \& Ali, A. R. (1993a). Comparative effects of iso-lated trees on their undercanopy environments in high- and low-rainfall savannas. Journal of Applied Ecology, 30, 143-155. http://dx.doi.org/10.2307/2404278

Belsky, A. J., Mwonga, S. M., \& Duxbury, J. M. (1993b). Effects of widely spaced trees and livestock grazing on understory environments in tropical savannas. Agroforestry Systems, 24, 1-20. http://dx.doi.org/10.1007/BF00705265

Calvo-Irabien, M. L., \& Islas-Luna, A. (1999). Predispersal Predation of an Understory Rainforest Herb Aphelandra aurantiaca (Acanthaceae) in Gaps and Mature Forest. American Journal of Botany, 86(8), 1108-1113. http://dx.doi.org/10.2307/2656973

Carrow, R. N. (1996). Drought resistance aspects of turfgrasses in the southeast: Root-shoot responses. Crop Sci., 36, 687-94. http://dx.doi.org/10.2135/cropsci1996.0011183X003600030028x

Chandran, R. S., \& Singh, M. (2003). Survey and control of Brazil pulsey (Richardia Brasiliensis) in Florida Citrus. Proc Fla State Hort Soc., 116, 211-214. 
Chapin, F. S., Bloom, A. J., Field, C. B., \& Waring, R. H. (1987). Plant Responses to Multiple Environmental Factors. Bioscience, 37(1), 49-57. http://dx.doi.org/10.2307/1310177

Colón, S. M., \& Lugo, A. E. (2006). Recovery of a Subtropical Dry Forest After Abandonment of Different Land Uses. Biotropica, 38(3), 354-364. http://dx.doi.org/10.1111/j.1744-7429.2006.00159.x

Fearnside, P. M., \& Guimara es. W. M. (1996). Carbon uptake by secondary forests in Brazilian Amazonia. Forest Ecology and Management, 80, 35-46. http://dx.doi.org/10.1016/0378-1127(95)03648-2

Fensham, R. J., \& Holman, J. E. (1999). Temporal and spatial patterns in drought related tree dieback in Australian savanna. J. Appl. Ecol., 36, 1035-1050. http://dx.doi.org/10.1046/j.1365-2664.1999.00460.x

Fernandez. O. N. (2003). Establishment of Cynodon dactylon from stolon and rhizome fragments. Weed Research, 43, 130-138. http://dx.doi.org/10.1046/j.1365-3180.2003.00324.x

Guariguata, M. R., \& Ostertag, R. (2001). Neotropical secondary succession: Changes in structural and functional characteristic. Forest Ecol. Manage., 148, 185-206. http://dx.doi.org/10.1016/S0378-1127(00)00535-1

Guglielmini, A. C., \& Satorre, E. H. (2004). The effect of non-inversion tillage and light availability on dispersal and spatial growth of Cynodon dactylon. Weed Research, 44, 366-374. http://dx.doi.org/10.1111/j.1365-3180.2004.00409.x

Holl, K., Loik, M., Lin, E., \& Samuels, I. (2000). Tropical montane forest restoration in Costa Rica: Overcoming barriers to dispersal and establishment. Restoration Ecology, 8, 339-349. http://dx.doi.org/10.1046/j.1526-100x.2000.80049.x

Hooper, E., Legendre, P., \& Condit, R. (2005). Barriers to forest regeneration of deforested and abandoned land in Panama. Journal of Applied Ecology, 42, 1165-1174. http://dx.doi.org/10.1111/j.1365-2664.2005.01106.x

Huang, R., Duncan, R., \& Carrow, R. N. (1997b). Root spatial distribution and activity of four turfgrass species in response to localized drought stress. Int. Turf. Soc. Res. J., 8, 681-9.

Manzungu. E., \& Mtali, L. (2012). An Investigation into the Spatial and Temporal Distribution of Fallow Land and the Underlying Causes in Southcentral Zimbabwe. Journal of Geography and Geology, 4(4), 62-75. http://dx.doi.org/10.5539/jgg.v4n4p62

Mapanda, F., \& Mavengahama, S. (2011). Assessment of selected soil nutrients and irrigation water quality in the dryland area of Chivi District, Zimbabwe. Scientific research and Essays, 6(14), 2918-2927.

Mapfumo, P., Mtambanengwe, F., Giller, K. E., \& Mpepereki, S. (2005). Tapping indigenous herbaceous legumes for soil fertility management by resource-poor farmer in Zimbabwe. Agriculture Ecosystem and Environment, 109, 221-233. http://dx.doi.org/10.1016/j.agee.2005.03.015

Marcum, L. B., Engelke, M. C., Morton, S. J., \&White, R. H. (1995). Rooting characteristics and associated $\begin{array}{llllll}\text { drought resistance of zoysia grass. Agron. } & \text { J., } & \text { 87, } & \text { 534-8. }\end{array}$ http://dx.doi.org/10.2134/agronj1995.00021962008700030023x

Mavedzenge, B. Z., Murimbarimba, F., \& Mudzivi, C. (1999). Experiences of farmer participation in soil fertility research in southern Zimbabwe. Manag. Afr. Soils, 5, 19.

McClanahan, T., \& Wolfe, R. (1993). Accelerating forest succession in a fragmented landscape: the role of birds and perches. Conservation Biology, 7(2), 279-288. http://dx.doi.org/10.1046/j.1523-1739.1993.07020279.x

Mordelet, P., \& Menaut, J. C. (1995). Influence of trees on above-ground production dynamics of grasses in a humid savanna. J. Veg. Sci., 6, 223-28. http://dx.doi.org/10.2307/3236217

Moyo, S. (2006). The evolution of Zimbabwe's land acquisition. In M. Rukuni, P. Tawonezvi, C. Eicher, M. Munyuki-Hungwe \& P. Matondi (Eds.), Zimbabwe's agriculture revolution revisited (pp. 144-160). Harare: University of Zimbabwe Publications.

Mpofu, I. D. T. (2005). Nutritional biochemistry laboratory manual, Department of Animal science, University of Zimbabwe

Muir-Leresche, K. (2006). Agriculture in Zimbabwe. In M. Rukuni, P. Tawonezvi, C. Eicher, Munyuki-Hungwe \& P. Matondi (Eds.), Zimbabwe's agricultural revolution revisited (pp. 94-114). Harare: University of Zimbabwe Publications.

Muir-Leresche, K. (2004). Agriculture in Zimbabwe. In M. Rukuni, P. Tawonezvi \& E. Eicher (Eds.), Zimbabwe agricultural revolution, Harare, University of Zimbabwe Publications. 
Nepstad, D. C., Uhl, C., Pereira, C. A., \& Cardosa da Silva, J. M. (1996). A comparative study of tree establishment in pasture and mature forest of Eastern Amozonia. Oikos, 76. http://dx.doi.org/10.2307/3545745

Ngobo, Martine, P., Weise, Stephan, F., \& Mcdonald, Morag A. (2004). Revisiting the Performance of Natural Fallows in Central Africa. Scandinavian Journal of Forest Research, 19, S4, 14-24. http://dx.doi.org/10.1080/14004080410034029

Nyamadzawo, G., Nyamugafata, P., Chokowo, R., \& Giller, K. E. (2003). Partioning of simulated rainfall in a kaolinitic soil under improved fallow-maize rotation in Zimbabwe. Agroforestry Systems, 59, 207-214. http://dx.doi.org/10.1023/B:AGFO.0000005221.67367.fd

Nyoka, R., Chikumba, N., Chakoma, I., Mazaiwana, P., Mukombe, N., \& Magwenzi, N. (2004). Evaluation and screening of forage legumes for sustainable integration into Crop-Livestock farming systems of Wedza District. In A. Whitbread \& B. C. Pengelly (Eds.), Tropical Legumes for Sustainable Farming Systems in Southern Africa and Australia (pp. 58-64). Australian Centre for International Research (ACIAR) Proceedings No. 115.

Reiners, W. A., Bouwman, A. F., Parsons, W. F. J., \& Keller, M. (1994). Tropical rain forest conversion to pastures: changes in vegetation and soil properties. Ecological Applications, 4, 363-377. http://dx.doi.org/10.2307/1941940

Sibanda, S., \& Khombe, C. (2006). Livestock research and development. In M. Rukuni, P. Tawonezvi, Eicher, C., Munyuki-Hungwe, \& P. Matondi (Eds.), Zimbabwe's agricultural revolution revisited (pp. 439-458). Harare: University of Zimbabwe Publications.

Spooner, D. M, Cusick, A. W., Hall, G. F., \& Baskin, J. M. (1985). Observations on the distribution and ecology of Sida Hermaphrodita (1) Rusby (Malvaceae) SIDA 11(2), 215-225.

Uhl, C. (1987). Factors controlling succession following slash and- burn agriculture in Amazonia. Journal of Ecology, 60, 675-695.

Van Wijk, M. T., \& Rodriguez-Iturbe, I. (2002). Tree-grass competition in space and time: insights from a simple cellular automata model based on ecohydrological dynamics. Water Resource Research, 38, 18.11-18.15.

Vincent, V., \& Thomas, R. G. (1961). An Agricultural survey of Southern Rhodesia. Part I. The Agro-ecological survey. Government Printer. Salisbury, Federation of Rhodesia and Nyasaland, p. 147.

Voeks, R. A. (1996). Tropical Forest Healers and Habitat Preference. Economic Botany, 50(4), 381-400. http://dx.doi.org/10.1007/BF02866520

Wadsworth, F. H. (1997). Forest production for tropical America. Agriculture Handbook 710. U.S. Department of Agriculture, Forest Service, Washington, D.C.

Weltzin, J. F., \& Coughenour, M. B. (1990). Savanna tree influence on understorey vegetation and soil nutrients in north-western Kenya. J. Veg. Sci., 1, 325-334. http://dx.doi.org/10.2307/3235707

Whitlow, R. (1985). Conflicts in Land Use in Zimbabwe: Political, Economic and Environmental Perspectives. Land Use Policy, 2(4), 309-322. http://dx.doi.org/10.1016/0264-8377(85)90029-8

Whittaker, J. B. (2001). Insects and plants in a changing atmosphere. Journal of Ecology, 89(4), 507-518. http://dx.doi.org/10.1046/j.0022-0477.2001.00582.x

Zingore, S., Murwira, H. K., Delve, R. J., \& Giller, K. E. (2007). Influence of nutrient management strategies on variability of soil fertility, crop yields and nutrient balances on smallholder farms in Zimbabwe. Agriculture, Ecosystems and Environment, 119, 112-126. http://dx.doi.org/10.1016/j.agee.2006.06.019

\section{Copyrights}

Copyright for this article is retained by the author(s), with first publication rights granted to the journal.

This is an open-access article distributed under the terms and conditions of the Creative Commons Attribution license (http://creativecommons.org/licenses/by/3.0/). 